\title{
Rapid colonisation by nematodes on organic and inorganic substrata deployed at the deep-sea Lucky Strike hydrothermal vent field (Mid-Atlantic Ridge)
}

\author{
Daniela Zeppilli $^{1,2}$ • Ann Vanreusel $^{3}$. \\ Florence Pradillon $^{1} \cdot$ Sandra Fuchs $^{1} \cdot$ Perrine Mandon $^{1}$. \\ Tristan James ${ }^{1}$ - Jozée Sarrazin ${ }^{1}$
}

Received: 30 December 2014 / Revised: 26 March 2015 / Accepted: 21 May 2015 /Published online: 9 June 2015

(C) The Author(s) 2015. This article is published with open access at Springerlink.com

\begin{abstract}
Despite the fragmented nature of hydrothermal vent (HV) fields, nascent vent sites are rapidly colonized by a pool of regional species. While succession of large animals at vents is relatively well established, we lack information on the associated meiofauna, in particular, on nematodes. The aim of the present study is to investigate the process of colonisation after 9 months of organic (wood and bone) and inorganic (slate) substrata by nematode assemblages deployed at the Eiffel Tower hydrothermal edifice on the Lucky Strike vent field on the Mid-Atlantic Ridge (MAR), at varying distances from visible hydrothermal activity. Abundance, biomass and diversity of colonising nematodes were compared with the results from an earlier similar two-year experiment. Near the vents, nematodes preferred inorganic substrata while in areas not influenced by vent activity, organic substrata were preferred. Nematode females dominated at almost all sites while numerous females at the ovigerous stage and juveniles were reported near the vent emissions, suggesting that nematode populations reproduce well after
\end{abstract}

Communicated by P. Martinez Arbizu

Daniela Zeppilli

Daniela.Zeppilli@ifremer.fr

1 IFREMER, Centre Brest, REM/EEP/LEP, Institut Carnot Ifremer-EDROME, ZI de la pointe du diable, CS10070, F-29280 Plouzané, France

2 Institut Universitaire Européen de la Mer, Laboratoire des sciences de l'environnement marin (UMR6539 CNRS/IRD/UBO), Université de Brest, rue Dumont d'Urville, 29280 Plouzané, France

3 Department of Biology, Marine Biology Section, Ghent University, Krijgslaan 281, S8, 9000 Ghent, Belgium just 9 months. Our nine-month experiment on the MAR showed that the type of substratum influenced significantly the composition of colonising nematodes, while after two years, the community structure was instead influenced by hydrothermal activity.

Keywords Nematodes $\cdot$ Colonization substrata $\cdot$ Wood . Bone $\cdot$ Slate $\cdot$ Mid-Atlantic Ridge $\cdot$ Hydrothermal vents

\section{Introduction}

Hydrothermal vents (HVs) are extreme environments where percolating cold seawater $\left(\sim 2-4{ }^{\circ} \mathrm{C}\right)$ penetrates the fractured oceanic crust. Being heated and enriched with reduced chemicals, the hydrothermal fluid emerges from the seafloor at temperatures up to $400{ }^{\circ} \mathrm{C}$ (Van Dover 2000). Hydrothermal organisms are adapted to the presence of extreme environmental conditions (high concentrations of reduced compounds, heavy metals and radionucleides, low oxygen level, and elevated temperatures; Sarradin et al. 1999; Charmasson et al. 2009). Despite the apparent harshness of the environment, HVs are hot-spots of high productivity and biomass when compared to the surrounding deep-sea benthos (Cuvelier et al. 2014). In addition, hydrothermal habitats are ephemeral and they have a longevity that is directly related to volcanic, tectonic and magmatic processes (Van Dover 2000). As hot fluid venting is transient, hydrothermal vent sites have ephemeral lifespans ranging from years (e.g. HV $9^{\circ} 50^{\prime} \mathrm{N}$ at the East Pacific Rise (EPR); Shank et al. 1998; Lutz et al. 2008) to decades or, exceptionally, centuries [e.g., the Mid-Atlantic Ridge, (MAR); Humphris et al. 2002]. Distances between HV fields are variable (up to hundreds of kilometres; Murton et al. 1994; German et al. 
1996). In addition to their remoteness, hydrodynamic and physical barriers (e.g., faults) can contribute to the isolation of hydrothermal vent fauna (Desbruyères et al. 2001).

Despite the significant degree of separation between HV fields, nascent vent sites are rapidly (months/years) colonized by a pool of regional species, even when the nearest populated hydrothermal vent is situated several kilometres away (Tunnicliffe et al. 1997; Shank et al. 1998; Tsurumi and Tunnicliffe 2001; Marcus et al. 2009). In 2006, a pilot study was set out to obtain better comprehension of community dynamics, colonization and recruitment patterns of local fauna around the Eiffel Tower edifice on the Lucky Strike vent field. For this, a series of six substrata (wood and slate) were deployed for two years before recovery (Cuvelier et al. 2014, and references therein). Results of this pilot study suggested that the local physical and chemical water conditions (mainly temperature and chemical compound concentrations) rather than the substratum type were the most important factors influencing the settlement and colonization of local fauna, although biological interactions appeared to be important (Cuvelier et al. 2014). Previous colonisation experiments at vents using inorganic substrata showed that colonisation patterns were influenced by a complex interaction between the composition of the surrounding community, variability in microhabitat conditions and biological interactions (Mullineaux et al. 2003; Govenar and Fisher 2007; Kelly et al. 2007). Gaudron et al. (2010) and Cuvelier et al. (2014) performed the first studies that also included the deployment of organic substrata (wood) in chemosynthetic environments and revealed that organic substrata attracted both chemosynthetic fauna as well as other opportunistic species.

Whilst mega- and macrofauna in HVs have been studied since their discovery, the ecology of meiofaunal organisms has only recently been included in vent studies (Tsurumi et al. 2003; Zekely et al. 2006a, b; Limén et al. 2007; Gollner et al. 2007, 2010a, b; Copley et al. 2007; Sarrazin et al. in press). Several HV habitats, from inactive bare basalts (Gollner et al. 2010b) and sediments (Vanreusel et al. 1997) to diffuse flow areas colonized by macrofaunal assemblages (Zekely et al. 2006a, c), host meiofaunal communities characterized by low abundance and diversity, linked with the abiotic and biotic conditions of the habitat (Gollner et al. 2010b; Zekely et al. 2006a, c; Degen et al. 2012). In most cases, nematodes and copepods are the most abundant meiofaunal organisms (Vanreusel et al. 2010; Zeppilli et al. submitted). The nematodes identified in vents can belong to families and genera already known from non-vent habitats (Dinet et al. 1988; Vanreusel et al. 1997; Zekely et al. 2006c; Sarrazin et al. in press). In some hydrothermal vents such as at the North Fiji Basin (Vanreusel et al. 1997) and Izu-
Ogasawara Arc in the western North Pacific Ocean (Setoguchi et al. 2014), none of the nematode species found in hydrothermal sediments occurred in the surrounding abyssal areas. Conversely, at the EPR, several nematode vent species have been found in abyssal sediments surrounding hydrothermal vent fields (Gollner et al. 2010b, 2015).

While succession of large animals at vents is relatively well observed (Sen et al. 2014), we know much less on the associated meiofauna and, in particular, on nematodes (Gollner et al. 2013). A study on mussel beds of different ages (4 to $>20$ years) showed that nematodes were less abundant and diverse at younger sites (Copley et al. 2007). Volcanic eruptions would negatively impact nematodes that may require long periods to colonize a newly lava-flooded area (Gollner et al. 2013). Recolonisation of vents by nematodes following volcanic eruptions appears to be strongly linked to the survival of populations in nearby undisturbed topographic features (Gollner et al. 2013).

The aim of the present study is to investigate the process of colonisation of organic and inorganic substrata by nematode assemblages at deep-sea HVs. Two types of organic substrata (wood and bone) and one type of inorganic substratum (slate) were deployed at the Eiffel Tower hydrothermal edifice on the Lucky Strike vent field on the Mid-Atlantic Ridge (MAR) for 9 months, at varying distances from visible hydrothermal activity. Wood and bone were chosen due to their organic nature, their wide distribution in the oceans (Smith and Baco 2003; Schwabe et al. in press) and their potential as evolutionary stepping stones for hydrothermal vent colonization (Distel et al. 2000; Lorion et al. 2009). As inorganic substratum, slate was chosen due to its basalt-like smoothness and inert characteristics. We investigated abundance, biomass and diversity of colonising nematodes and compared our data with the twoyear experiment performed at the same location by Cuvelier et al. in 2014 to answer the two following questions:

i) Are nematodes mostly influenced by the type of substratum or by environmental constraints (e.g., hydrothermal activity) at an early stage of colonisation (9 months)?

ii) Are there differences in the nematode community after 9 months and 2 years for the same substrata and locations?

\section{Materials and methods}

\section{Study site}

The Lucky Strike vent field is situated on the MAR, south of the Azores (Fig. 1). It is a large vent field with a central lava 

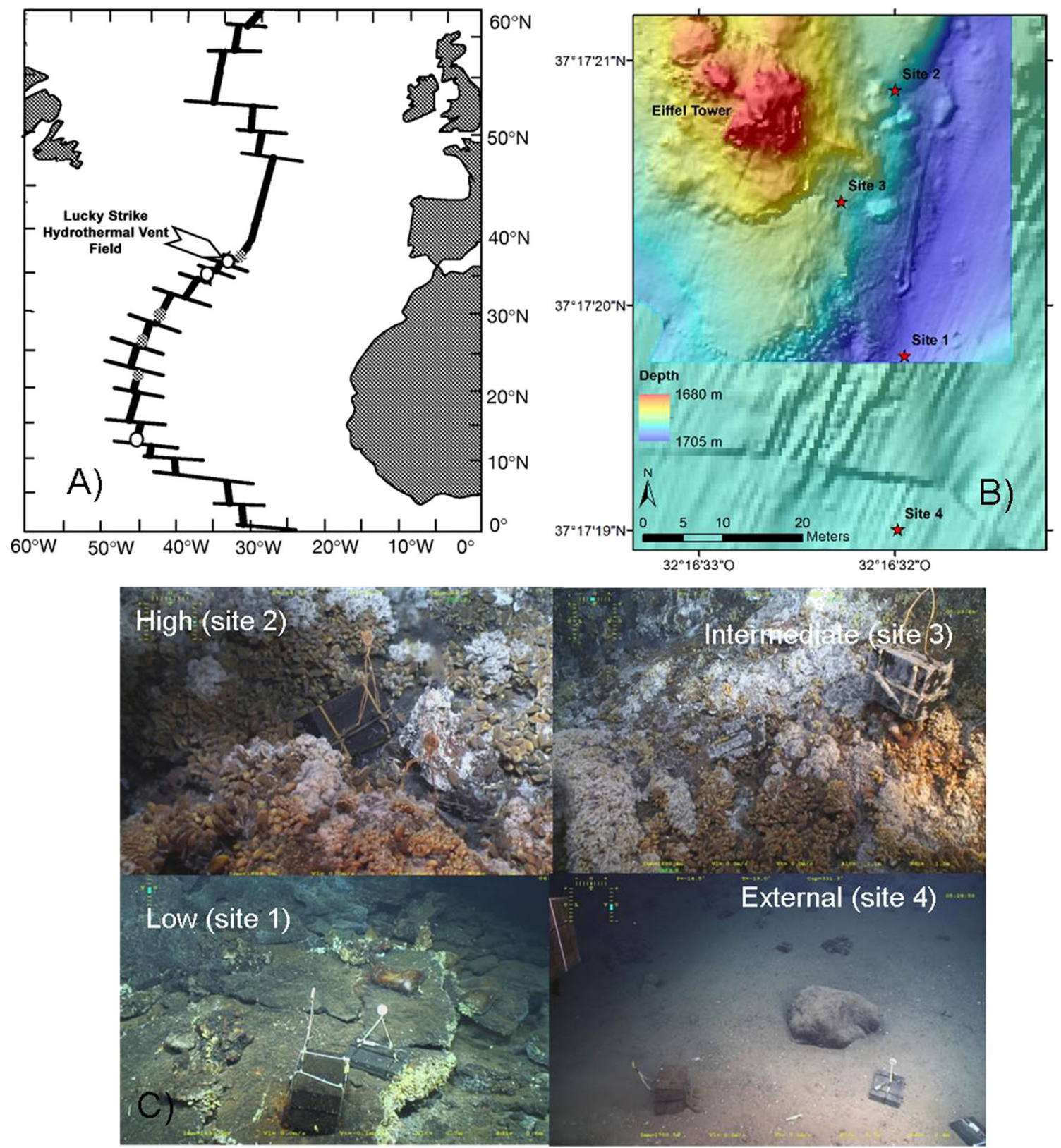

Fig. 1 Location of the Lucky Strike vent field on the Mid-Atlantic Ridge (MAR) at $37^{\circ} 17.59 \mathrm{~N}, 32^{\circ} 169 \mathrm{~W}$ (a). The locations of the sites where different substrata were deployed around the Eiffel Tower edifice $(\mathbf{b})$ are reported. On each locality, slate, wood, and bone were deployed (c)

lake with an 200-m diameter, surrounded by three volcanic cones (Ondréas et al. 2009). Several hydrothermal edifices can be found around the lava lake. The Eiffel Tower edifice is a well-defined active edifice $11 \mathrm{~m}$ high and one of the mostvisited sites within the Lucky Strike vent field. It has been the focus of ecological research over the last ten years (e.g., Van Dover et al. 1996; Comtet and Desbruyeres 1998; Desbruyères et al. 2001; Cuvelier et al. 2009; Cuvelier et al. 2011a; Cuvelier et al. 2012; Sarrazin et al. in press; Matabos et al. in press), and also recently in regards to short-term (Sarrazin et al. 2014) and long-term (Cuvelier et al. 2011b) temporal variation studies.

\section{Experimental design and sample collection}

Three types of substrata, one inorganic (basalt-like slate, A) and two organic (wood, B and bone, C), were deployed during the MOMARSAT 2010 cruise (October 2010 on the research vessel Pourquoi Pas?), on four different sites (1 to 4) up and around the Eiffel Tower edifice (Fig. 1 and Table 1), at varying distances from visible hydrothermal activity. The sites chosen correspond to those reported by Cuvelier et al. (2014), with the exception of one additional external site (site 4) ca. $25 \mathrm{~m}$ from the Eiffel Tower edifice. Therefore, substrata at sites 1 and 
Table 1 Location, depth and temperature of the sites at the Eiffel Tower edifice (MAR) where different substrata were deployed in 2010 and recovered in 2011 (avg.=average). Fluid inputs in percentage were calculated using the formula provided by Sarradin et al. (2009) for the Eiffel Tower edifice $(\%=0.314 \mathrm{~T}-1.38)$

\begin{tabular}{|c|c|c|c|c|c|c|c|c|}
\hline \multirow[t]{2}{*}{ Site } & \multirow[t]{2}{*}{ Emission } & \multirow{2}{*}{$\begin{array}{l}\text { Latitude } \\
\text { (N) }\end{array}$} & \multirow{2}{*}{$\begin{array}{l}\text { Longitude } \\
\text { (W) }\end{array}$} & \multirow{2}{*}{$\begin{array}{l}\text { Depth } \\
\text { (m) }\end{array}$} & \multicolumn{3}{|l|}{$\mathrm{T}^{\circ} \mathrm{C}$} & \multirow{2}{*}{$\begin{array}{l}\% \text { Fluid } \\
\text { Inputs }\end{array}$} \\
\hline & & & & & Avg. & Min. & Max. & \\
\hline 2 & High & $37^{\circ} 17.3484^{\prime}$ & $32^{\circ} 16.5333^{\prime}$ & 1699 & 5.7 & 4.3 & 7.7 & 0.41 \\
\hline 3 & Intermediate & $37^{\circ} 17.3404^{\prime}$ & $32^{\circ} 16.5379^{\prime}$ & 1698 & 5.2 & 4.4 & 6.7 & 0.25 \\
\hline 1 & Low & $37^{\circ} 17.3299^{\prime}$ & $32^{\circ} 16.5325^{\prime}$ & 1704 & 4.9 & 4.3 & 6.7 & 0.16 \\
\hline 4 & External & $37^{\circ} 17.3181^{\prime}$ & $32^{\circ} 16.5331^{\prime}$ & 1705 & 4.6 & 4.3 & 4.9 & 0.06 \\
\hline
\end{tabular}

3 were deployed at the base of the south side of the Eiffel Tower, at respective distances of $3 \mathrm{~m}$ and 4-5 $\mathrm{m}$ from the edifice. Substrata 1 (A, B and C; Fig. 1c) were placed in the visibly least populated and least hydrothermal active region (low hydrothermal influence site; Fig. 1c). Substrata 3 (A, B and C) were put on a crack with diffuse venting, bordered by Bathymodiolus azoricus mussels and microbial mats (intermediate hydrothermal influence site; Fig. 1c). Substrata 2 (A, B and C) were situated at site 2 on a spur of the Eiffel Tower edifice towards the north-west (high hydrothermal influence site; Fig. 1c). Finally, substrata 4 (A, B and C) were situated at site 4 between two hydrothermal edifices $69 \mathrm{~m}$ from site 2 , $52 \mathrm{~m}$ from site 3 and $27 \mathrm{~m}$ from site 1 . Only substrata A2, B2 and C2 were located directly on the edifice and were situated in the most densely populated area of the three deployment sites, within less than half a meter from various fluid exits, surrounded by dense Bathymodiolus azoricus assemblages. Each slate substratum was equipped with an autonomous NKE ST 6000 temperature probe, which measured temperature every 15 minutes (Table 1). Temperature is used here as a proxy for hydrothermal influence and a percentage of hydrothermal fluid input at each site was calculated using the formula proposed by Sarradin et al. (2009) for the same area (Table 1). Each colonization substrata was measured to evaluate the surface available for colonization. 3D imaging techniques were used to reconstruct the substrata using a calibration grid and photographs taken at different angles before their deployment (coll. M. Aron, ISEN engineering school). The surface available for colonization in each substratum is reported in Table 2.

Nine months later, in July 2011, the substrata were recovered during the MOMARSAT 2011 cruise. However the bones situated at sites 1 and 4 had disappeared. We suspect that large predators are responsible as sharks were observed several times during our substratum deployments. Both substrata deployment and recovery were carried out with the remotely operated vehicle (ROV) Victor6000. Upon recovery, all substrata were placed in individual isotherm sampling boxes and brought to the surface.

\section{Nematode abundance and biomass}

On board, the faunal samples were pre-sieved through 1000-, 250 - and $20-\mu \mathrm{m}$ mesh nets. Samples were preserved in seawater-buffered formalin (10\%). In the lab, nematodes were counted under a stereomicroscope. The nematode biomass was calculated from the biovolume, which was estimated from all specimens per replicate using the Andrassy formula $(\mathrm{V}=\mathrm{L}$ $\times \mathrm{W}^{2} \times 0.063 \times 10^{-5}$, with body length, $\mathrm{L}$, and width, $\mathrm{W}$, expressed in $\mu \mathrm{m}$; Andrassy 1956). The carbon contents were identified as $40 \%$ of the dry weight (Feller and Warwick 1988). Nematode measurements were taken using an AxiozoomV16 stereomicroscope (400× magnification) using the software Zen 2012 (blue edition).

\section{Nematode biodiversity}

From each substratum sample, 200 randomly collected nematodes were mounted on slides after formalin-ethanol-glycerol treatment to prevent dehydratation (Danovaro 2010) and identified to the species level according to Platt and Warwick (1983, 1988), Warwick et al. (1998), and the recent literature dealing with new nematode genera and species from the Atlantic Ocean. Unknown species were reported under the name of the genus and then as sp1, sp2 and so on.

NSR was calculated as the total number of species collected for each site. Nematode species diversity (H', using logbase e) was measured using the Shannon-Wiener diversity index, with the evenness as the Pielou index $(\mathrm{J})$. The Margalef diversity index (D) was estimated as $\mathrm{D}=(\mathrm{S}-1 / \ln \mathrm{N})$, where $\mathrm{S}$ is the number of nematode species and $\mathrm{N}$ is the number of individuals in the sample. In order to facilitate comparison among samples, the expected number of nematode species for a theoretical random sample of 100 individuals, ES (100), was calculated. All indices were calculated using the PRIMER6 software (Plymouth Marine Laboratory, UK; Clarke 1993).

The trophic diversity of the nematodes was determined by analysing trophic groups, as reported by Wieser (1953). The nematodes were divided into four groups, as follows: (i) no buccal cavity or a fine tubular one, as selective (bacterial) feeders (1A); (ii) large, but unarmed, buccal cavity, as non- 
Table 2 Size and respective colonisable surface area of each substratum deployed in 2010 and recovered in 2011

\begin{tabular}{|c|c|c|c|c|c|}
\hline \multicolumn{2}{|c|}{ Substrate } & \multicolumn{3}{|c|}{ Size of the substratum (mm) } & \multirow{2}{*}{$\begin{array}{l}\text { Colonisable surface } \\
\text { area }\left(\mathrm{mm}^{2}\right)\end{array}$} \\
\hline Name & Kind & $\mathrm{X}$ & $\mathrm{Y}$ & $\mathrm{Z}$ & \\
\hline A1 & Slate & 215 & 309 & 63 & 173,045 \\
\hline A2 & Slate & 241 & 326 & 54 & 175,441 \\
\hline A3 & Slate & 211 & 309 & 54 & 166,149 \\
\hline A4 & Slate & 219 & 307 & 54 & 170,398 \\
\hline B1 & Wood & 193 & 321 & 220 & 228,018 \\
\hline B2 & Wood & 218 & 302 & 224 & 304,895 \\
\hline B3 & Wood & 235 & 305 & 219 & 297,343 \\
\hline B4 & Wood & 195 & 292 & 197 & 285,344 \\
\hline $\mathrm{C} 1$ & Bone & 244 & 342 & 194 & 226,916 \\
\hline $\mathrm{C} 2$ & Bone & 155 & 263 & 122 & 139,992 \\
\hline $\mathrm{C} 3$ & Bone & 211 & 348 & 162 & 180,714 \\
\hline $\mathrm{C} 4$ & Bone & 269 & 335 & 17 & 171,150 \\
\hline
\end{tabular}

selective deposit feeders (1B); (iii) buccal cavity with scraping tooth or teeth epistrate or epigrowth feeders (2A); and (iv) buccal cavity with large jaws, as predators/omnivores (2B). The index of trophic diversity (ITD) was calculated as $\Theta$, where $\Theta=\mathrm{g}_{1}{ }^{2}+\mathrm{g}_{2}{ }^{2}+\mathrm{g}_{3}{ }^{2} \ldots+\mathrm{g}_{\mathrm{n}}{ }^{2}$, and $\mathrm{g}$ is the relative contribution (in terms of number of specimens) of each trophic group to the total number of individuals, and $n$ is the number of trophic groups (Heip et al. 1985). For $n=4, \Theta$ ranges from 0.25 (highest trophic diversity; i,.e. the four trophic groups each account for $25 \%$ of the nematode abundance) to 1.0 (lowest diversity; i.e., when one trophic group accounts for $100 \%$ of the nematode abundance). Nematode trophic structure was calculated based on the nematode biomass matrix.

The maturity index (MI) of nematode populations was calculated from life strategies ( $\mathrm{r}-\mathrm{k}$ ) of the nematodes for which these strategies are known. In order to identify colonization strategies, nematodes are divided into "colonizers" (comparable to r-strategists, characterized by a short life cycle, high colonization ability, and tolerance to disturbance, e.g., eutrophication, and anoxybiosis) and "persisters" (k-strategists with a low reproduction rate, long life cycle, and low colonization ability and tolerance to disturbance; the list of species with different life strategies is reported by Bongers et al. 1991). The MI was calculated according to the weighted mean of the individual genus scores: $\mathrm{MI}=\Sigma \mathrm{v}$ (i) X f(i), where $\mathrm{v}$ is the $\mathrm{c}-\mathrm{p}$ value (colonisers-persisters; ranging from 1, i.e., only opportunistic colonizers, to 5, i.e., only persisters) of the genus $\mathrm{i}$ (Bongers et al. 1991) and f(i) is the frequency of that genus.

\section{Statistical analyses}

Premised on the fact that these experiments are characterised by a lack of replicates, statistical analyses in this study are limited to a principal component analysis (PCA) and a nonparametric multivariate multiple regression analysis.

The Bray-Curtis similarity matrix (with data square-root transformed) was used for the PCA, which allowed visualization of between-site and between-substrata variations in the nematode assemblages after 9 months (PRIMER6 software, Plymouth Marine Laboratory, UK; Clarke 1993).

We evaluated the relationship after 9 months between nematode abundance, biomass, diversity (as nematode species composition, NSR, ITD and MI) and environmental variables (temperature and fluid inputs reported as high, medium, low, absent) and type of substrata (slate, wood and bone) conducting a non-parametric multivariate multiple regression analysis (DistLM: distance-based linear model) using the PERMANOVA + add-on package for PRIMER6 software (McArdle and Anderson 2001; Anderson et al. 2008). This method analyses and models the relationship between a multivariate data cloud and one or more predictor variables. It is based on a resemblance matrix and uses permutations rather than the restrictive Euclidean distance and normality assumptions which underlie the standard approach to linear modeling. For total abundance, biomass and diversity indices, the Euclidean distance was used as a resemblance measure, whereas for species composition, the analysis was based on BrayCurtis dissimilarities. Forward selection was carried out and the adjusted $\mathrm{R}^{2}$ was selected as the criterion to enable fitting of the best explanatory environmental variables in the model (Anderson et al. 2008). The results are provided as marginal and sequential tests. The marginal test revealed how much each variable explains when taken alone, ignoring all other variables. Following the results of this test, a sequential test was performed which examined whether the addition of that particular variable contributes significantly to the explained variation (Anderson et al. 2008). 


\section{Results}

\section{Environmental conditions}

The highest average temperature was recorded at the high emission site $\left(5.7{ }^{\circ} \mathrm{C}\right)$, followed by the intermediate $\left(5.2^{\circ} \mathrm{C}\right)$, and low emission sites $\left(4.9^{\circ} \mathrm{C}\right.$; Table 1$)$. The average temperature at the external site was $4.6^{\circ} \mathrm{C}$. Variation between the maximal and minimal temperatures was highest at the high emission site $\left(3.4^{\circ} \mathrm{C}\right)$ and lowest at the external site $\left(0.6^{\circ} \mathrm{C}\right)$. At a given site, temperature can be used as a proxy of hydrothermal influence since it correlates well with the chemical characteristics of the fluids (Sarradin et al. 1999; Sarradin et al. 2009). Using the formula provided by Sarradin et al. (2009) we calculated the $\%$ of fluid inputs (Table 1). At site 2 , the $\%$ of fluid inputs was $0.41,0.25$ at site $3,0.16$ at site 1 and 0.06 at the external site. Furthermore, a recent study on the Eiffel Tower edifice (De Busserolles et al. 2009) showed positive correlations between temperature and total dissolved sulphide and iron concentrations. For example, an increase of $0.5^{\circ}$ leads to 3 times more total dissolved sulphide, 120 times more total dissolved iron, and a pH reduction of 0.26 (De Busserolles et al. 2009).

\section{Nematode abundance on substrata recovered after 9 months}

The highest nematode density was reported in the wood located at the external site while the lowest was found on the wood located at the low emission site, with 242,006.1 and 381.5 ind $\mathrm{m}^{-2}$, respectively (Table 3 ). The abundance decreased with decreasing fluid emission in slate, with values 10 times lower at the external site, from 17,641.3 to 1250.0 ind $\mathrm{m}^{-2}$ (Table 3). Concerning the two recovered bones ( $\mathrm{C} 3$ and $\mathrm{C} 2)$, the abundance was higher at the intermediate site than at the high emission site, 4792.1 and 2807.3 ind $\mathrm{m}^{-2}$, respectively (Table 3 ).

\section{Nematode biomass on substrata recovered after 9 months}

Nematode biomass showed a similar pattern as that of abundance with the highest value on wood of the external site and the lowest on wood of the low emission site, respectively 9680.2 and $13.4 \mu \mathrm{gC} \mathrm{m}^{-2}$ (Table 3). High biomass values were also reported on the wood located at the high emission site $\left(2310.8 \mu \mathrm{gC} \mathrm{m}{ }^{-2}\right.$, Table 3$)$ due to the dominance of Oncholaimus sp. 1 in this site. The average biomass for individuals of this species $\left(3 \mu \mathrm{gC} \mathrm{m}{ }^{-2}\right)$ was 60 times higher than the average biomass reported for the other nematodes species $\left(0.05 \mu \mathrm{gC} \mathrm{m}^{-2}\right)$. On slate, the biomass decreased with decreasing fluid emission, from 829.1 to $116.3 \mu \mathrm{gC} \mathrm{m}{ }^{-2}$ (Table 3). Concerning the two recovered bones, the biomass was higher

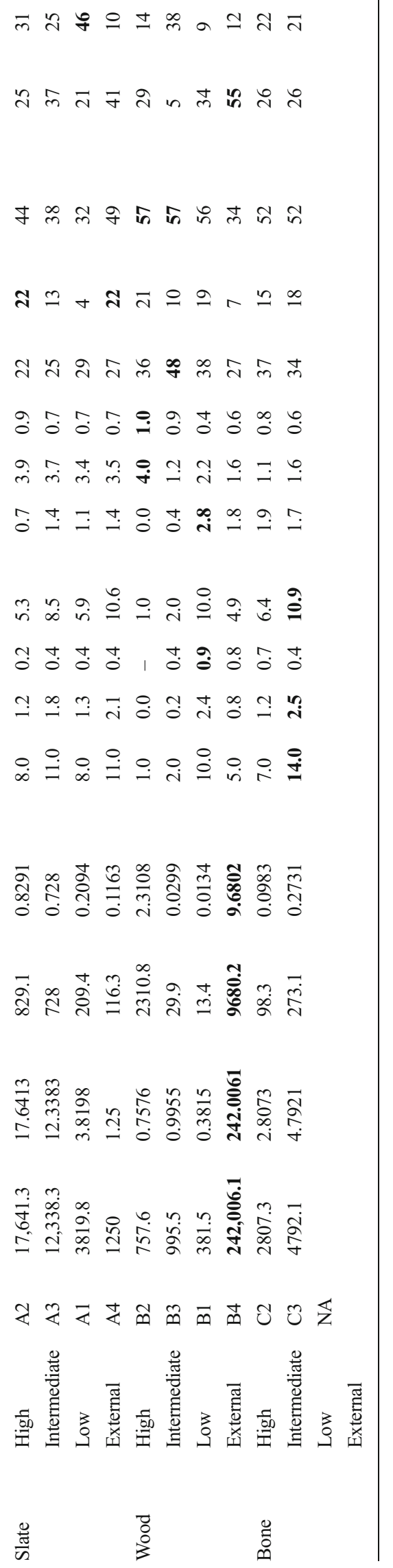


at the intermediate site $(\mathrm{C} 3)$ than at the high emission site (C2), 273.1 and $98.3 \mu \mathrm{gC} \mathrm{m}^{-2}$, respectively (Table 3).

\section{Nematode diversity in substrata recovered after 9 months}

Overall, 24 nematode species belonging to 20 genera and 12 families were identified. In slate substrata, Draconematidae was the dominant family. This family increased its dominance with increasing vent emission (from 76 to $93 \%$ of the total nematode abundance, from external to high emission sites, respectively; Fig. 2), while the family Monhysteridae increased its dominance with decreasing vent emission (from 4 to $16 \%$ of the total nematode abundance, from high to low emission sites, respectively; Fig. 2). On wood substrata, Monhysteridae was the dominant family, accounting for $42-$ $93 \%$ of the total nematode abundance, except for the high emission site (site 2) where Oncholaimidae totally dominated the community (Fig. 2). The family Microlaimidae was found only on the wood located in the low and external sites, accounting for 20 and $30 \%$ of the total nematode abundance, respectively (Fig. 2). Bones were largely dominated by Monhysteridae (92 and $74 \%$ of the total nematode abundance in high emission and intermediate sites, respectively; Fig. 2), followed by Microlaimidae at the high emission site $(6 \%)$ and Draconematidae at the intermediate site $(9 \%)$. The genus Cephalochaetosoma dominated slate substrata (75-90\%), while Halomonhystera dominated bone substrata (71-92 \%; Table 4). On wood, Oncholaimus dominated the site with highest hydrothermal activity (site 2, $100 \%$ ), Halomonhystera dominated the intermediate and low emission sites (sites 3 and 1, 42-93\%), while Thalassomonhystera dominated the external site (site 4, $61 \%$; Table 4).

NSR was highest on the bone recovered from the intermediate emission site (14 species) and lowest on the wood at the high emission site ( 1 species). On slate, 8 species were identified at the intermediate emission and external sites and 11 species were found at the high and low emission sites (Table 3). On wood, species richness was very low at the high and intermediate emission sites ( 1 and 2 species, respectively), while at the low emission and external sites, 10 and 5 species were respectively identified (Table 3 ). Considering each set of substrata, the highest species richness was recorded at the intermediate site (17 species), while the lowest was found at the high emission site (12 species).

The number of "exclusive" species reported at each site increased with decreasing influence of vent emission from 0 at the high emission site to 3 at the external site. Considering the substratum, seven species were exclusively reported on slate (representing $29 \%$ of the total richness), two species were exclusively reported on wood $(8 \%)$ and only one on bone ( $4 \%$, Fig. 3). At the high emission site, only one species (Oncholaimus sp.1) was shared by the three substrata and two species were shared between slate and bone (Cephalochaetosoma sp.1 and Halomonhystera sp.1; Fig. 3). At this site, five species were exclusively encountered on slate and four on bone. At the intermediate emission site, two species were shared by the three substrata (Cephalochaetosoma sp.1 and Halomonhystera sp.1) and five species were shared by slate and bone; while three species were exclusively reported on slate and six on bones (Fig. 3). At the low emission site, slate and wood shared five species, respectively showing five and three exclusive species (Fig. 3). At the external site, only 1 species was shared by wood and slate (Calomicrolaimus sp.1), while slate and wood, respectively, reported 11 and 4 exclusive species (Fig. 3).

On slate, deposit feeders, including selective (1A) and nonselective feeders (1B) dominated the trophic structure of nematodes, representing 90-95\% of the total nematode abundance, with selective feeders (1A) decreasing with increasing vent emission (Fig. 4). On wood, non-selective feeders (1B) dominated at all sites (49-93\%), except at the high emission site, where predators/omnivores (2B) represented $100 \%$ of the nematode community. On bone, non-selective feeders (1B) dominated the high (92\%) and intermediate sites (75\%). The ITD increased with increasing influence of vent emissions on all types of substrata (Table 3). The MI was particularly low on bone (1.1-1.6), and always high, between 3.5-3.9 on slate (Table 3). Wood substrata showed a low MI
Fig. 2 Nematode family composition found on the investigated substrata recovered after 9 months

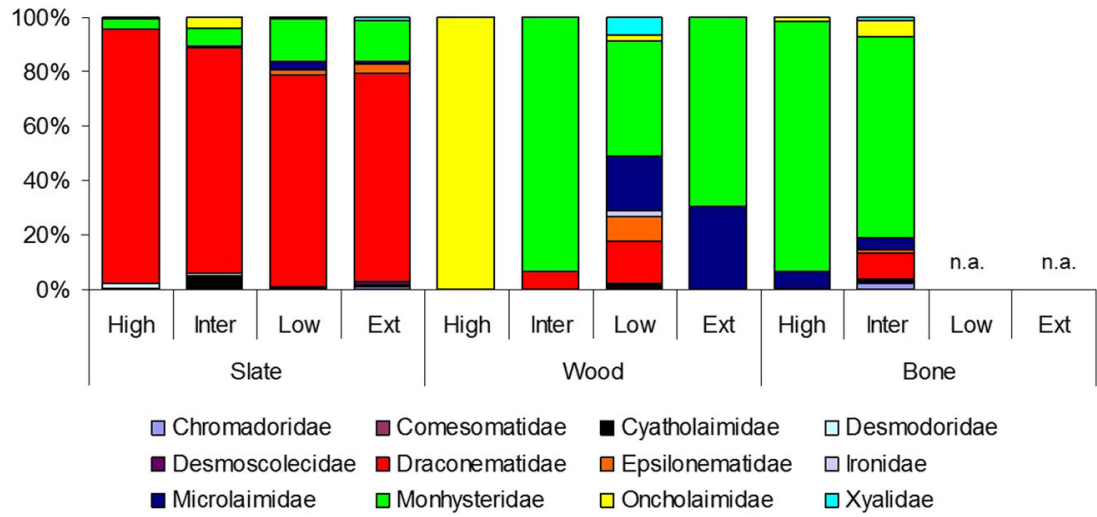


Table 4 List of nematode species encountered in the investigated substrata recovered after 9 months and relative abundance (\%). Highest values are highlighted in bold

\begin{tabular}{|c|c|c|c|c|c|c|c|c|c|c|}
\hline \multirow[b]{2}{*}{ Nematode species } & \multicolumn{4}{|l|}{ Slate } & \multicolumn{4}{|l|}{ Wood } & \multicolumn{2}{|l|}{ Bone } \\
\hline & $\begin{array}{l}\text { High } \\
\text { A2 }\end{array}$ & $\begin{array}{l}\text { Intermediate } \\
\text { A3 }\end{array}$ & $\begin{array}{l}\text { Low } \\
\text { A1 }\end{array}$ & $\begin{array}{l}\text { External } \\
\text { A4 }\end{array}$ & $\begin{array}{l}\text { High } \\
\text { B2 }\end{array}$ & $\begin{array}{l}\text { Intermediate } \\
\text { B3 }\end{array}$ & $\begin{array}{l}\text { Low } \\
\text { B1 }\end{array}$ & $\begin{array}{l}\text { External } \\
\text { B4 }\end{array}$ & $\begin{array}{l}\text { High } \\
\text { C2 }\end{array}$ & $\begin{array}{l}\text { Intermediate } \\
\text { C3 }\end{array}$ \\
\hline Aponema sp1 & 0.0 & 0.0 & 0.0 & 0.0 & 0.0 & 0.0 & 0.0 & 18.5 & 0.0 & 0.6 \\
\hline Calomicrolaimus sp1 & 0.0 & 0.0 & 0.0 & 0.9 & 0.0 & 0.0 & 0.0 & 10.4 & 0.7 & 2.9 \\
\hline Cephalochaetosoma $\mathrm{sp} 1$ & 90.0 & 76.8 & 77.4 & 74.5 & 0.0 & 6.6 & 15.6 & 0.0 & 0.7 & 9.2 \\
\hline Chromadorita sp1 & 0.3 & 0.7 & 0.0 & 0.9 & 0.0 & 0.0 & 0.0 & 0.0 & 0.0 & 2.3 \\
\hline Cobbia $\mathrm{sp} 1$ & 0.0 & 0.0 & 0.0 & 0.0 & 0.0 & 0.0 & 2.2 & 0.0 & 0.0 & 1.1 \\
\hline Desmodora marci & 1.3 & 1.1 & 0.0 & 0.0 & 0.0 & 0.0 & 0.0 & 0.0 & 0.0 & 0.6 \\
\hline Desmoscolex $\mathrm{sp} 1$ & 0.0 & 0.0 & 0.0 & 0.9 & 0.0 & 0.0 & 0.0 & 0.0 & 0.0 & 0.0 \\
\hline Dinetia $\mathrm{sp} 1$ & 3.3 & 5.6 & 0.0 & 1.9 & 0.0 & 0.0 & 0.0 & 0.0 & 0.0 & 0.0 \\
\hline Epsilonema $\mathrm{sp} 1$ & 0.3 & 0.7 & 1.4 & 1.9 & 0.0 & 0.0 & 8.9 & 0.0 & 0.0 & 1.1 \\
\hline Epsilonema $\mathrm{sp} 2$ & 0.0 & 0.0 & 0.5 & 0.9 & 0.0 & 0.0 & 0.0 & 0.0 & 0.0 & 0.0 \\
\hline Halomonhystera $\mathrm{sp} 1$ & 3.7 & 6.4 & 15.7 & 15.1 & 0.0 & 93.4 & 22.2 & 0.0 & 28.9 & 72.4 \\
\hline Halomonhystera $\mathrm{sp} 2$ & 0.0 & 0.0 & 0.0 & 0.0 & 0.0 & 0.0 & 20.0 & 20.0 & 16.3 & 0.6 \\
\hline Halomonhystera $\mathrm{sp} 3$ & 0.0 & 0.0 & 0.0 & 0.0 & 0.0 & 0.0 & 0.0 & 0.0 & 46.7 & 0.6 \\
\hline Metacomesoma sp1 & 0.0 & 0.0 & 0.5 & 0.0 & 0.0 & 0.0 & 0.0 & 0.0 & 0.0 & 0.0 \\
\hline Metepsilonema sp1 & 0.0 & 0.0 & 0.0 & 0.9 & 0.0 & 0.0 & 0.0 & 0.0 & 0.0 & 0.0 \\
\hline Microlaimus sp1 & 0.0 & 0.0 & 3.2 & 0.0 & 0.0 & 0.0 & 20.0 & 1.5 & 5.2 & 1.1 \\
\hline Molgolaimus sp1 & 0.3 & 0.4 & 0.0 & 0.0 & 0.0 & 0.0 & 0.0 & 0.0 & 0.0 & 0.0 \\
\hline Oncholaimus sp1 & 0.7 & 4.1 & 0.5 & 0.0 & 100.0 & 0.0 & 2.2 & 0.0 & 1.5 & 6.3 \\
\hline Paracanthonchus sp1 & 0.0 & 1.5 & 0.0 & 0.0 & 0.0 & 0.0 & 0.0 & 0.0 & 0.0 & 0.6 \\
\hline Paracanthonchus sp2 & 0.0 & 0.4 & 0.0 & 0.9 & 0.0 & 0.0 & 2.2 & 0.0 & 0.0 & 0.6 \\
\hline Paracyatholaimus sp1 & 0.0 & 2.2 & 0.9 & 0.0 & 0.0 & 0.0 & 0.0 & 0.0 & 0.0 & 0.0 \\
\hline Syringolaimus sp1 & 0.0 & 0.0 & 0.0 & 0.0 & 0.0 & 0.0 & 2.2 & 0.0 & 0.0 & 0.0 \\
\hline Thalassomonhystera vandoverae & 0.0 & 0.0 & 0.0 & 0.0 & 0.0 & 0.0 & 0.0 & 49.6 & 0.0 & 0.0 \\
\hline Theristus sp1 & 0.0 & 0.0 & 0.0 & 0.9 & 0.0 & 0.0 & 4.4 & 0.0 & 0.0 & 0.0 \\
\hline
\end{tabular}

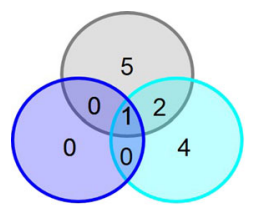

High

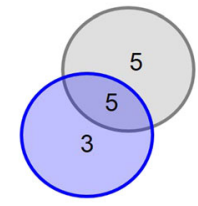

Low

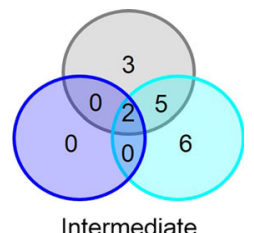

Intermediate

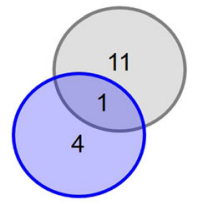

External
Slate $\bigcirc$ wood Bone

Fig. 3 Venn diagrams reporting the number of nematode species for each investigated site encountered after 9 months. The number of species reported in each circle represents the number of species exclusively found on one substratum type. The number of species reported in the intersections represents the shared species value at the intermediate emission site and a very high value of 4 at the high emission site (Table 3). It increased with increasing influence of vent emissions on slate (from 3.5 to 3.9), while it showed an opposite pattern on bone (1.1 and 1.6 at the high and intermediate sites, respectively; Table 3). The nematode sex ratio is reported in Table 3. Females dominated at all sites and on all substrata (32-57\%), except on the wood of the external site, where males dominated (55\%). An important number of gravid females were observed in all samples (4-22\%) with the highest number on slate at the high emission site where juveniles were also particularly abundant (representing up to $46 \%$ of the nematode community).

\section{Nematode colonization after 9 months compared with the results from the 2 years experiment}

The abundance of nematodes decreases with decreasing influence of vent emissions on slate recovered both after 9 and 24 months (Fig. 5). Higher abundance was always found after 
Fig. 4 Nematode trophic structure of colonisation substrata recovered after 9 months. 1A: selective (bacterial) feeders; 1B: non-selective deposit feeders; $2 \mathrm{~A}$ : epistrate feeders; 2B: predators/ omnivores

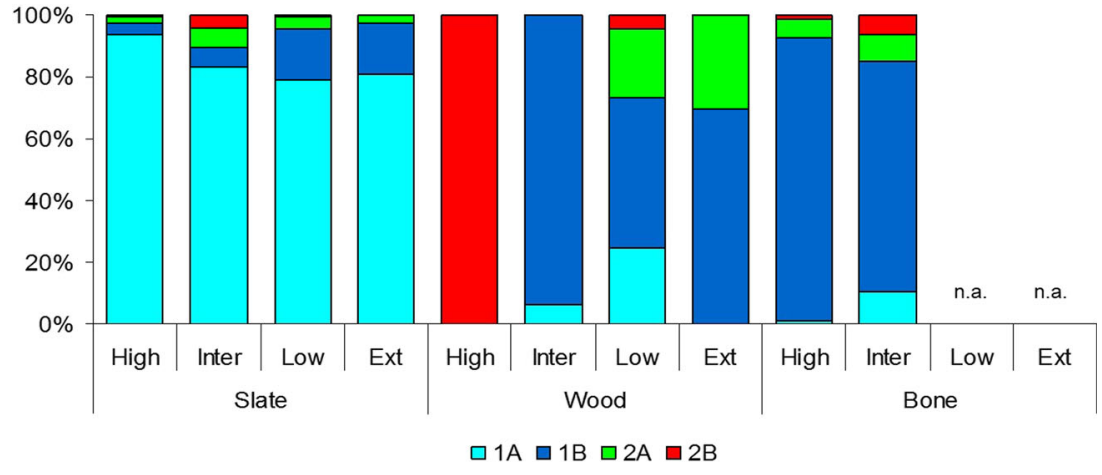

9 months. On wood, the intermediate emission site showed the highest abundance value after 9 months and the lowest after 24 months (Fig. 5; for details, see Cuvelier et al. 2014). The nematode family composition on slate and wood from different sites is reported in Fig. 6. After 9 months, Draconematidae dominated slate while on wood, Oncholaimidae dominated at high emission sites and Monhysteridae at intermediate and low emission sites. After 2 years, Draconematidae dominated at high and low emission sites both on slate and wood while we reported the co-dominance of Draconematidae, Microlaimidae and Monhysteridae at the intermediate emission site both on slate and wood (Fig. 6; for details, see Cuvelier et al. 2014).

\section{Statistical results}

PCA analyses revealed that the wood situated in the high emission site (B2) was strongly separated from the other substrata (Fig. 7), due to the presence of Oncholaimus sp.1. PCA of the species composition data also revealed a discrimination between inorganic substrata (slate) and organic substrata (with the exception of B2; Fig. 7).

The DistLM analysis showed the environmental variables that were best correlated to the observed distribution patterns (Table 5). The environmental data available did not explain the differences in nematode abundance, biomass and diversity (expressed as NSR). However, differences in nematode species composition were significantly explained by the type of substrata $(22 \%)$. The type of substrata also significantly explained $60 \%$ of the differences in the MI, while temperature explained $50 \%$ of the observed differences in the ITD; nevertheless, feeding types were different on slate and wood at high emission sites.

\section{Discussion}

\section{Nematode colonisation patterns on organic and inorganic substrata recovered after 9 months}

Nematode abundances reported in this study are consistent with available data from other Atlantic deep-sea vents (Zekely et al. 2006a; Cuvelier et al. 2014; Sarrazin et al. in press; Table 6), confirming that nematodes are part of hydrothermal vent communities (Sarrazin et al. in press). To our knowledge, information on hydrothermal vent nematode biomass is reported exclusively by two studies (Vanreusel et al. 1997; Gollner et al. 2007). In the deep-sea HV of the North Fiji Basin, the mean weight was between 0.23 and $0.35 \mu \mathrm{g}$ wet wt in active HVs and $0.15 \mu \mathrm{g}$ wet wt in inactive sites (Vanreusel et al. 1997). In the present study, nematode mean wet weight can reach values 100 times higher than in Vanreusel et al. 1997, with a peak of $30.5 \mu \mathrm{g}$ wet wt in the wood of the most active site (site 2). On the EPR, nematode biomass was 20 times lower than the values observed in the present study (Gollner et al. 2007). Biomass values reported in this study are for most samples consistent with values reported from a nematofauna investigated in a seamount close to the
Fig. 5 Nematode abundance on colonisation substrata (slate and wood) recovered after 9 months and after 2 years

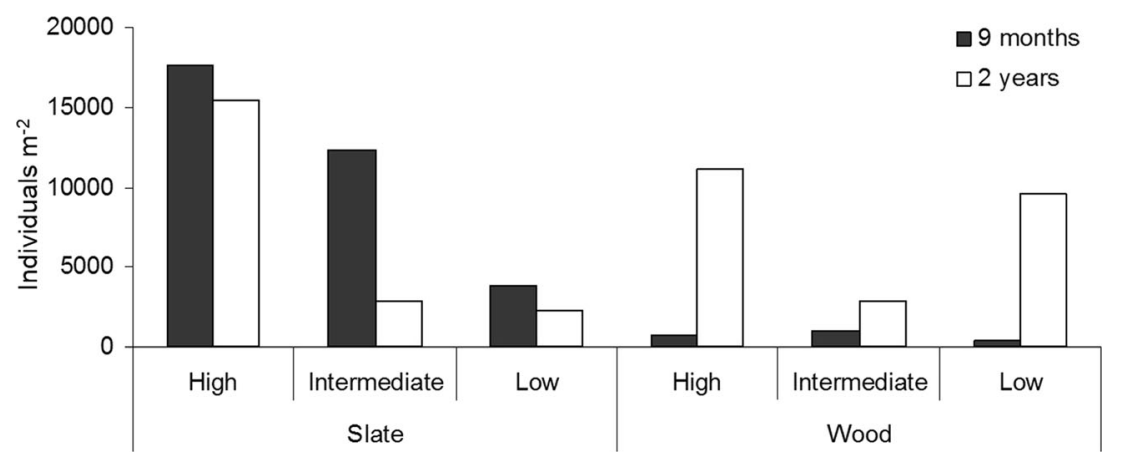


9 months

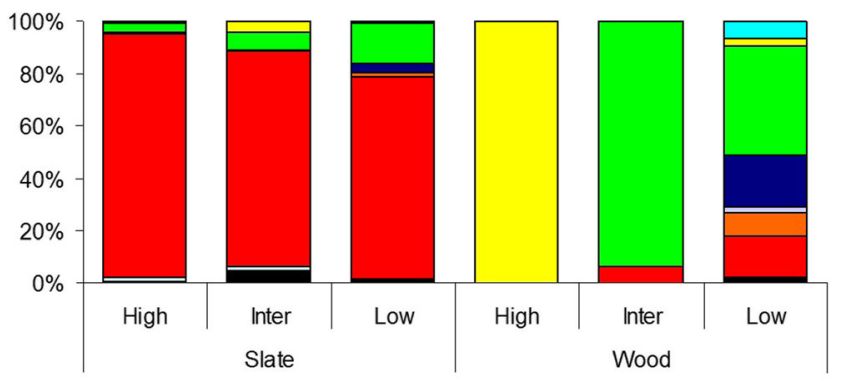

2 years

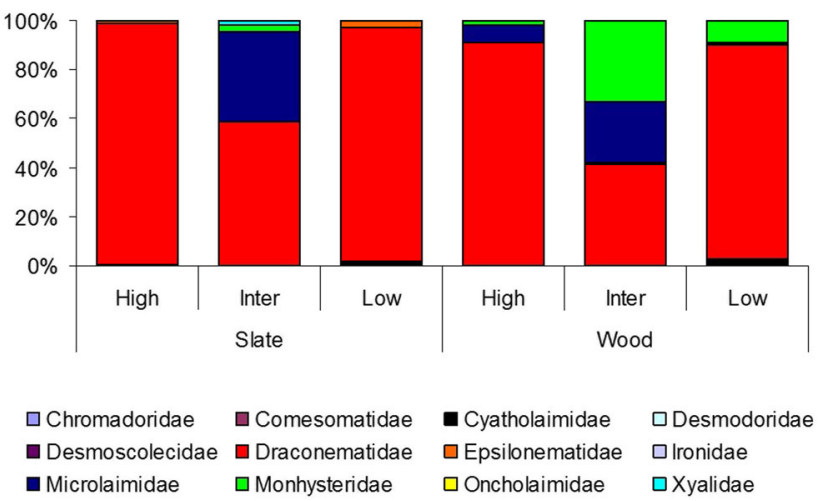

Fig. 6 Nematode family composition of colonisation substrata (slate and wood) recovered after 9 months and after 2 years

Lucky Strike hydrothermal vent field (Condor Seamount; Zeppilli et al. 2013). The same trend observed for abundance was observed for nematode biomass in inorganic substrata with an increase of values with increasing influence of vent emission. An opposite trend (increase of biomass with decreasing vent emission) was observed on bone, while on wood, we observed values of biomass 100 times higher in the highest emission and external sites than in the others. At the high emission site, this unexpected peak of nematode biomass is due to the dominance of the big nematode Oncholaimus sp.1, which can reach $7-8 \mathrm{~mm}$ in length as adults. This nematode is 10 times longer than the nematode lengths reported by Vanreusel et al. (1997) in the deep-sea HV of the North Fiji Basin. Big nematodes belonging to the Oncholaimidae family were reported worldwide in association with shallow water vent emission (Zeppilli and Danovaro 2009) but rarely reported in deep-sea hydrothermal vents and always in very low abundance (Vanreusel et al. 2010; Sarrazin et al. in press). This study showed that, in some cases, deep-sea HVs can support rich nematode communities in terms of standing stocks (both abundance and biomass), and further studies are needed to reveal the spatial distribution of nematodes in this peculiar ecosystem. The high biomass values on wood at the external site are explained by the high densities of small colonizers such as Monhysterids and Microlaimus. Microlaimus is known as an early colonizer of disturbed or new habitats (Lee et al. 2001; Muthumbi et al. 2004; Van Gaever et al 2009). It colonized the wood in very high abundances without any vent emission influence.

The nematodes identified in this study belong to families and genera already known from the Lucky Strike HV field (Zekely et al. 2006a; Cuvelier et al. 2014; Sarrazin et al. in press), with exception for the genus Oncholaimus that was for the first time reported in deep-sea Atlantic HVs, considering both meiofauna and macrofauna studies. Cephalochaetosoma and Halomonhystera, reported as the dominant genera in the nematofauna associated with mussel beds in the MAR (Sarrazin et al. in press), dominated slate and bone recovered after 9 months (Table 4). Nematodes reported from the MAR (Zekely et al. 2006a; Cuvelier et al. 2014; Sarrazin et al. in press), the North Fiji Basin (Vanreusel et al. 1997), and other Pacific hydrothermal sites (Flint et al. 2006; Zekely et al. 2006a; Gollner et al. 2007, 2010b) were dominated by few nematode taxa. The richest nematode diversity was reported in soft sediments associated with Bathymodiolus mussels from the North Fiji basin with over 30 genera identified (Vanreusel et al. 1997). In this study, we observed a total of 24 species belonging to 20 genera, with a local species diversity varying between 1 and 14 species, confirming the trend of low evenness described by Sarrazin et al. (in press). Similar to Gollner et al. (2013), we observed that active vent sites were dominated by a few generalists, while rare and exclusive species increased with distance from a vent's influence.

Cephalochaetosoma sp. 1 and Halomonhystera sp. 1 were both able to colonise slate and bone at the high emission site and all substrata at the intermediate emission site. Oncholaimus sp. 1 was able to colonise all the substrata investigated in this study, while this species dominated the wood at the high emission site, reaching high biomass values for the total nematode community. The genus Oncholaimus is known to tolerate extreme geothermal and hypersaline conditions and high sulphide concentrations in shallow hydrothermal vents (Gerlach and Riemann 1973; Thiermann et al. 1994). The species Oncholaimus campylocercoides, found in HVs of the Aegean Sea as well as in brackish waters in the Baltic and Black Seas (Thiermann et al. 1994, 1997), can produce sulphur-containing droplets when exposed to hydrogen sulphide (Thiermann et al. 1994), potentially reducing the toxic effect of $\mathrm{H}_{2} \mathrm{~S}$. The accumulation of elemental sulphur also provides an energetic 'deposit' for later oxidation to thiosulphate, sulphite, or sulphate under oxic conditions (Thiermann et al. 2000). Our study showed that the genus Oncholaimus (only occasionally found in deep-sea vents; Vanreusel et al. 1997) could colonise deep-sea HVs, becoming an important component (in term of abundance and biomass) of vent fauna.

The fact that females dominated almost at all sites, and that all substrata near the vent emission harboured high numbers of juveniles and females at the ovigerous stage supports the idea 
Fig. 7 PCA of investigated colonisation substrata recovered after 9 months

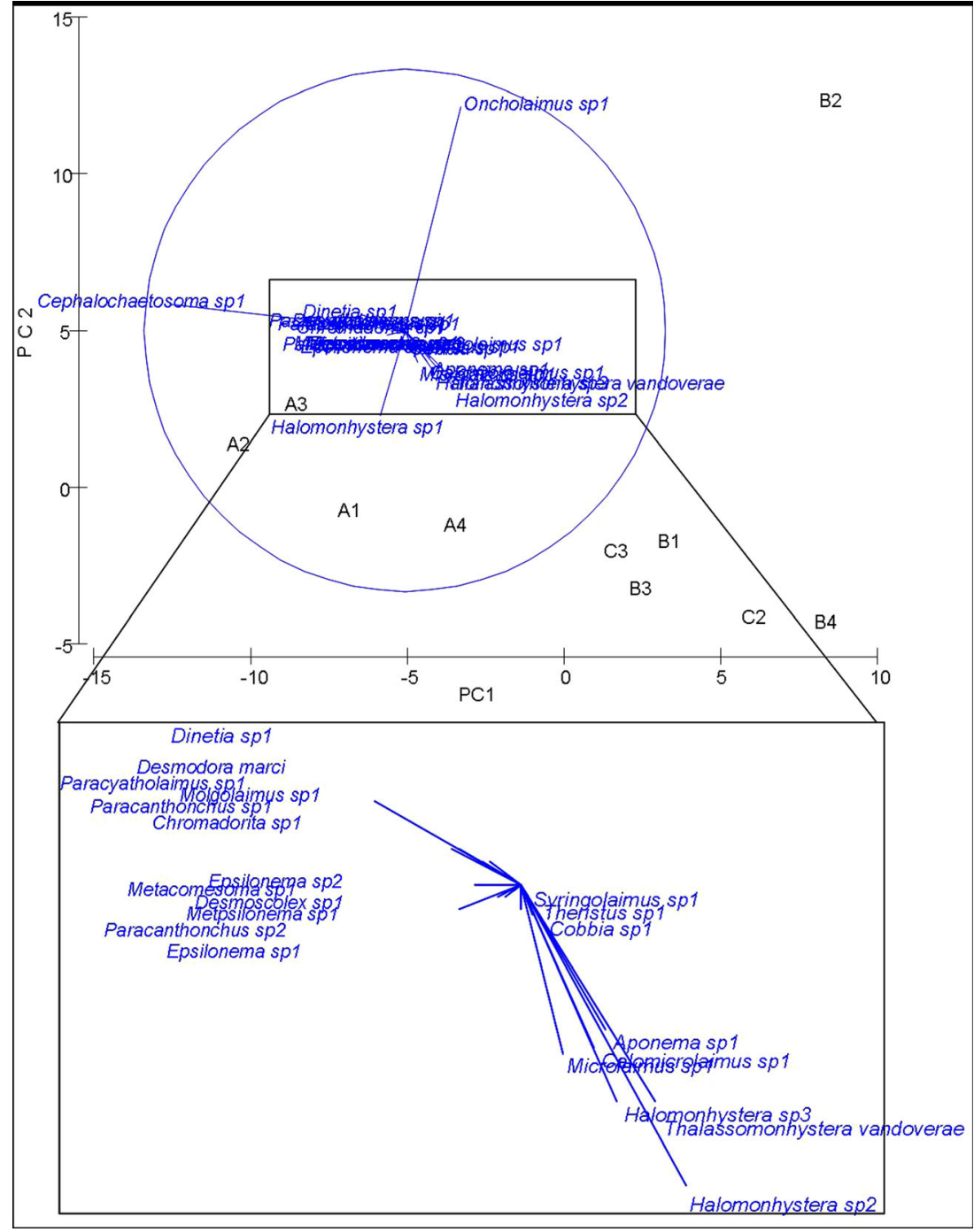

that nematodes were reproducing and, thus, represented a well-established population. The discovery of a high

Table 5 Results of the DistLM analysis (Selection criterion: adjusted $\mathrm{R}^{2}$ ) highlighting the effect of different variables on nematode abundance, biomass and diversity in substrata recovered after 9 months (NSR: abundance of copepodites and nauplii in deep-sea HVs was recently reported by Sarrazin et al. (in press), reconsidering

Nematode Species Richness; SS: sum of squares; F: F statistic; P: probability level; ${ }^{* * *} P<0.001 ;{ }^{* *} P<0.01 ;{ }^{*} P<0.05$; ns: not significant)

\begin{tabular}{|c|c|c|c|c|c|c|}
\hline & Variables & SS & $F$ & $p$ & & Variance $(\%)$ \\
\hline Nematode abundance & Vent emission & $1.2 \mathrm{E}+10$ & 2.5121 & 0.17 & ns & 24 \\
\hline \multirow[t]{2}{*}{ Nematode biomass } & Vent emission & $1.25 \mathrm{E}+07$ & 1.4796 & 0.299 & ns & 16 \\
\hline & Temperature & $1.01 \mathrm{E}+07$ & 1.227 & 0.318 & ns & 13 \\
\hline Nematode species richness & Temperature & 13.404 & 0.77315 & 0.385 & ns & 9 \\
\hline \multirow[t]{3}{*}{ Nematode species composition } & Substrata & 5233.9 & 2.2405 & 0.038 & $*$ & 22 \\
\hline & Vent emission & 3328.4 & 1.5168 & 0.162 & ns & 14 \\
\hline & Temperature & 2713.8 & 1.2875 & 0.282 & ns & 11 \\
\hline \multirow[t]{2}{*}{ Index of trophic diversity } & Temperature & 0.16424 & 8.0736 & 0.02 & $*$ & 50 \\
\hline & Substrata & $2.09 \mathrm{E}-02$ & 1.0312 & 0.348 & $\mathrm{~ns}$ & 6 \\
\hline \multirow[t]{2}{*}{ Maturity index } & Substrata & 7.5348 & 12.072 & 0.015 & $*$ & 60 \\
\hline & Temperature & 1.5186 & 3.0594 & 0.123 & ns & 12 \\
\hline
\end{tabular}




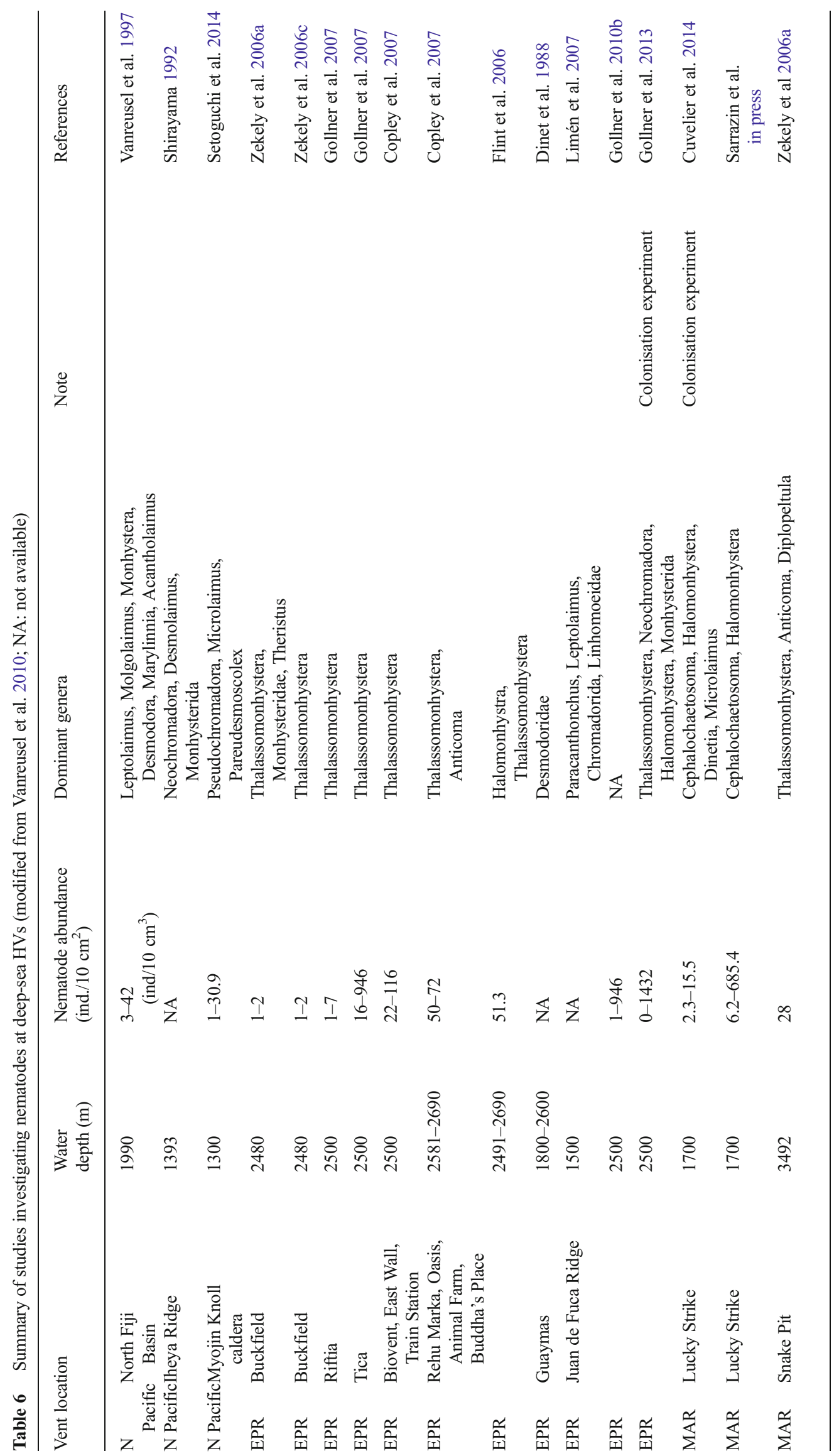


previous assumptions suggesting that copepod larval stages were located outside active hydrothermal areas. Furthermore, we observed that the genus Halomonhystera showed an ovoviviparous reproduction strategy. The ovoviviparous reproductive mode has already been described for Monhysteridae living in harsh environmental conditions (Van Gaever et al. 2006), but it is being reported for the first time for deep-sea HVs.

Nematode studies at the EPR revealed that the diversity of nematodes changed along a gradient of fluid emission (over a temperature gradient of $>50^{\circ} \mathrm{C}$; Gollner et al. 2010b), emphasizing the role of environmental conditions. In this study, we observed that after 9 months, nematode communities were mainly influenced by the type of substratum and that environmental conditions appeared to play a minor role (Fig. 7 and Table 5), even though small variations in temperature correspond to significant variations of associated chemical conditions and hydrothermal fluid inputs (Sarradin et al. 2009). Also, trophic diversity showed marked differences among the different types of substratum with selective deposit feeders dominating the inorganic slate and non-selective depositfeeders dominating the organic wood and bone substrata.

\section{Comparison of nematode colonisation patterns on organic and inorganic substrata after 9 months and 2 years}

Information about succession of nematodes in deep-sea HVs are poor (Gollner et al. 2013). After a volcanic eruption at the EPR, Gollner et al. (2013) showed that nematodes required long periods to colonize new lava-flooded areas in greater numbers and richness. Conversely, in our study we observed that nematodes colonised both organic and inorganic substrata in high abundance and diversity after just 9 months. The study of Gollner et al. (2013) investigated the recovery after a disturbance that affected a whole region, killing almost all nematodes present in this area. Nematodes migrating from distant areas may have required longer time to recolonize the perturbed areas (Gollner et al. 2013). In Lucky Strike experiments (9-month and 24-month sets), nematode abundance on inorganic substrata increased with increasing vent emissions (Fig. 5). Only after 2 years did we observe higher nematode abundances on organic substrata than on inorganic substrata (15 times higher at the high emission site and 30 times higher at the low emission site). This preliminary study suggests that inorganic substrata were preferred by colonising nematodes in the early succession stage, while organic substrata required a long term to host well-established nematode communities. We can hypothesize that opportunistic colonisers are successful during the early colonisation processes selecting organic substrata, but they experienced mortality shortly after settling due the extreme condition of this site.

Similar to what was observed by Gollner et al. (2013), we observed that the most abundant species during early succession were also the dominant species in this area (Cephalochaetosoma sp.1 and Halomonhystera sp. 1; Sarrazin et al. in press). The only exception in our study was the presence of Oncholaimus sp. 1, dominant on the wood of the high emission site recovered after 9 months and never reported before in Lucky Strike HV nematofauna. This species was not found after 24 months.

Investigating the nematode family composition in substrata recovered after 9 months and 2 years (Fig. 6), we observed that in the former Draconematidae dominated inorganic substrata, while Monhysteridae dominated the organic substrata (with the exception of the high emission site, where Oncholaimidae dominated). After 2 years, we observed differences in nematode composition between sites with different vent emission influence, regardless of the type of substratum (Fig. 6). The 9-month experiment at the MAR showed that the type of substratum significantly influenced the composition of colonising nematodes, while after 2 years, nematode composition was more influenced by hydrothermal activity (Cuvelier et al. 2014).

\section{Conclusions}

This study followed the previous pilot deployment of paired wood/slate panels in close proximity of hydrothermal emissions on and around the Eiffel Tower hydrothermal edifice performed by Cuvelier et al. 2014. The most important limitation of these experiments was the lack of replicates, urging caution in the interpretation of the results. The use of large substrata allowed the concurrent colonisation by meio- and macrofauna, allowing biotic interactions to structure the composition of communities. The analysis of nematodes recovered on organic and inorganic substrata deployed at the deep-sea Lucky Strike HV field (MAR) provided answers to the original questions:

i) Nematodes were able to colonise both organic and inorganic substrata in an early colonisation stage (9 months). The most abundant species during early succession correspond to the dominant species in this area (Cephalochaetosoma sp.1 and Halomonhystera $s p .1)$ with the exception of Oncholaimus sp. 1, which was able to colonise all the substrata investigated and dominated the wood at the high emission site, reaching high biomass values. Active vent sites were dominated by a few generalists, while rare and exclusive species increased with distance from the vent. The presence of important numbers of females at the ovigerous stage and juveniles near the vent emission, suggest that nematodes are already well established near the vent emission after 9 months. 
ii) Our data suggested that inorganic substrata is preferred by colonising nematodes in the early succession stage, while the establishment of the nematode community required more time to colonise the organic substrata. We observed that after 9 months, Draconematidae dominated inorganic substrata, while Monhysteridae dominated the organic substrata. The 9-month experiment on the MAR showed that the type of substratum significantly influenced the composition of colonising nematodes, while after 2 years, HV activity was the predominant factor regardless the type of substratum.

Acknowledgments We thank the captains and crews of the $\mathrm{R} / \mathrm{V}$ Pourquoi Pas? for their steadfast collaboration in the success of the MoMARSAT cruises. We are also grateful to the Victor6000 ROV pilots for their patience and constant support. We also warmly thank the LEP technical team for its valuable help both at sea and in the lab. DZ was supported by the "Laboratoire d'Excellence" LabexMER (ANR-10LABX-19), co-funded by a grant from the French government under the program "Investissements d'Avenir" by a grant from the Regional Council of Brittany (SAD programme), and by the project "Deep-sea hYdrothermal Vent nematodes as potential source of new Antibiotics" (DYVA) funded by Fondation Total and Ifremer. This project is part of the EMSO-Açores research program that benefited from an ANR research grant (ANR LuckyScales).

Open Access This article is distributed under the terms of the Creative Commons Attribution 4.0 International License (http:// creativecommons.org/licenses/by/4.0/), which permits unrestricted use, distribution, and reproduction in any medium, provided you give appropriate credit to the original author(s) and the source, provide a link to the Creative Commons license, and indicate if changes were made.

\section{References}

Anderson MJ, Gorley RN, Clarke KR (2008) PERMANOVA+ for PRIM ER: guide to software and statistical methods. PRIMER-E, Plymouth

Andrassy I (1956) The determination of volume and weight of nematodes. Acta Zool Hung 2:1-15

Bongers T, Alkemade R, Yeates GW (1991) Interpretation of disturbanceinduced maturity decrease in marine nematode assemblages by means of the Maturity Index. Mar Ecol Prog Ser 76:135-142

Charmasson S, Sarradin PM, Le Faouder A, Agarande M, Loyen J, Desbruyères D (2009) High levels of natural radioactivity in biota from deep-sea hydrothermal vents: a preliminary communication. J Environ Radioact 100:522-526

Clarke KR (1993) Non parametric multivariate analyses of changes in community structure. Aust J Ecol 18:117-143

Comtet T, Desbruyeres D (1998) Population structure and recruitment in mytilid bivalves from the Lucky Strike and Menez Gwen hydrothermal vent fields $\left(37^{\circ} 17^{\prime} \mathrm{N}\right.$ and $37^{\circ} 50^{\prime} \mathrm{N}$ on the Mid-Atlantic Ridge). Mar Ecol Prog Ser 163:165-177

Copley JTP, Flint HC, Ferrero TJ, Van Dover CL (2007) Diversity of meiofauna and free-living nematodes in hydrothermal vent mussel beds on the northern and southern East Pacific Rise. J Mar Biol Assoc UK 87:1141-1152

Cuvelier D, Sarrazin J, Colaço A, Copley J, Desbruyères D, Glover AG, Tyler P, Santos RS (2009) Distribution and spatial variation of hydrothermal faunal assemblages at Lucky Strike (Mid-AtlanticRidge) revealed by high-resolution video image analysis. Deep Sea Res Part I 56:2026-2040

Cuvelier D, Sarradin PM, Sarrazin J, Colaço A, Copley JT, Desbruyeres D, Glover AG, Santos RS, Tyler PA (2011a) Hydrothermal faunal assemblages and habitat characterisation at the Eiffel Tower edifice (Lucky Strike, Mid-Atlantic Ridge). Mar Ecol Evol Perspect 32: 243-255

Cuvelier D, Sarrazin J, Colaço A, Copley JT, Glover AG, Tyler PA, Santos RS, Desbruyeres D (2011b) Community dynamics over 14 years at the Eiffel Tower hydrothermal edifice on the Mid-Atlantic Ridge. Limnol Oceanogr 56(5):1624-1640

Cuvelier D, de Busserolles F, Lavaud R, Floc'h E, Fabri MC, Sarradin PM, Sarrazin J (2012) Biological data extraction from imagery e How far can we go? A case study from the Mid-Atlantic Ridge. Mar Environ Res 82:15-27

Cuvelier D, Beesau J, Ivanenko VN, Zeppilli D, Sarradin PM, Sarrazin J (2014) Colonisation and diversity patterns on organic and inorganic substrata and the influence of hydrothermal activity at Atlantic deepsea vents. Deep Sea Res Part I 87:70-81

Danovaro R (2010) Methods for the study of deep-sea sediments their functioning and biodiversity. CRC Press, Boca Raton

De Busserolles F, Sarrazin J, Gauthier O, Gelinas Y, Fabri MC, Sarradin PM, Desbruyeres D (2009) Are spatial variations in the diets of hydrothermal fauna linked to local environmental conditions? Deep Sea Res Part II 56(19-20):1649-1664

Degen R, Riavitz L, Gollner S, Vanreusel A, Plum C, Bright M (2012) Community study of tubeworm-associated epizooic meiobenthos from deep-sea cold seeps and hot vents. Mar Ecol Prog Ser 468: $135-148$

Desbruyères D, Biscoito M, Caprais JC, Colaço A, Comtet T, Crassous $\mathrm{P}$, Fouquet Y, Khripounoff A, Le Bris N, Olu K, Riso R, Sarradin PM, Segonzac M, Vangriesheim A (2001) Variations in deep-sea hydrothermal vent communities on the Mid-Atlantic Ridge near the Azores plateau. Deep Sea Res Part I 48:1325-1346

Dinet A, Grassle F, Tunnicliffe V (1988) Premières observations sur la meiofaune des sites hydrothermaux de la dorsale East-Pacifique (Guaymas, 211N) et de l'Exlorer Ridge. Oceanol Acta 85:7-14

Distel DL, Baco AR, Chuang E, Morrill W, Cavanaugh CM, Smith CR (2000) Do mussels take wooden steps to deep-sea vents? Nature 403(6771):725-726

Feller RJ, Warwick RM (1988) Energetics. In: Higgin RP, Thiel H (eds) Introduction to the study of meiofauna. Smithsonian Institution Press, Washington, pp 181-196

Flint HC, Copley JTP, Ferrero TJ, Van Dover CL (2006) Patterns of nematode diversity at hydrothermal vents on the East Pacific Rise. Cah Biol Mar 47:365-370

Gaudron SM, Pradillon F, Pailleret M, Duperron S, Le Bris N, Gaill F (2010) Colonization of organic substrates deployed in deep-sea reducing habitats by symbiotic species and associated fauna. Mar Environ Res 70(1):1-12

Gerlach SA, Riemann F (1973) The Bremerhaven checklist of aquatic nematodes. A catalogue of Nematoda Adenophorea excluding the Dorylaimida. Veröff Inst Meeresforsch Bremerhav $1: 1-404$

German CR, Parson LM, Bougault F, Coller D, Critchley M, Dapoigny A, Day C, Eardley D, Fearn A, Flewellen C, Kirk R, Klinkhammer G, Landure JY, Ludford E, Miranda M, Needham HD, Patching J, Pearce R, Pelle H, Radfordknoery J, Rouse I, Scott J, Stoffregen P, Taylor P, Teare D, Wynar J (1996) Hydrothermal exploration near the Azores Triple Junction: tectonic control of venting at slowspreading ridges? Earth Planet Sci Lett 138:93-104

Gollner S, Zekely J, Govenar B, Le Bris N, Nemeschkal HL, Fisher CR, Bright M (2007) Tubeworm-associated permanent meiobenthic communities from two chemically different hydrothermal vent sites on the East Pacific Rise. Mar Ecol Prog Ser 337:39-49 
Gollner S, Ivanenko VN, Arbizu PM, Bright M (2010a) Advances in taxonomy, ecology, and biogeography of dirivultidae (Copepoda) associated with chemosynthetic environments in the deep sea. PLoS ONE 5:e9801

Gollner S, Riemer B, Martinez Arbizu P, Le Bris N, Bright M (2010b) Diversity of meiofauna from the $9^{\circ} 50^{\prime} \mathrm{N}$ East Pacific rise across a gradient of hydrothermal fluid emissions. PLoS ONE 5(8):e12321. doi:10.1371/journal.pone.0012321

Gollner S, Miljutina M, Bright M (2013) Nematode succession at deepsea hydrothermal vents after a recent volcanic eruption with the description of two dominant species. Org Divers Evol 13:349-371

Gollner S, Govenar B, Fisher CR, Bright M (2015) Size matters at deepsea hydrothermal vents: different diversity and habitat fidelity patterns of meio- and macrofauna. Mar Ecol Prog Ser 520:57-66

Govenar B, Fisher CR (2007) Experimental evidence of habitat provision by aggregations of Riftia pachyptila at hydrothermal vents on the East Pacific Rise. Mar Ecol Evol Perspect 28:3-14

Heip C, Vincx M, Vranken G (1985) The ecology of marine nematodes. Oceanogr Mar Biol Annu Rev 23:399-489

Humphris SE, Fornari DJ, Scheirer DS, German CR, Parson LM (2002) Geotectonic setting of hydrothermal activity on the summit of Lucky Strike seamount (37 Degrees 17 ' N, Mid-Atlantic Ridge). Geochem Geophys Geosyst 3. doi:10.1029/2001GC000284

Kelly NE, Metaxas A, Butterfield DA (2007) Spatial and temporal patterns of colonization by deep-sea hydrothermal vent invertebrates on the Juan de Fuca Ridge, NE Pacific. Aquat Biol 1:1-16

Lee HJ, Vanhove S, Peck LS, Vincx M (2001) Recolonisation of meiofauna after catastrophic iceberg scouring in shallow Antarctic sediments. Polar Biol 24:918-925

Limén H, Levesque C, Juniper SK (2007) POM in macro-/meiofaunal food webs associated with three flow regimes at deep-sea hydrothermal vents on Axial Volcano, Juan de Fuca Ridge. Mar Biol 153: 129-139

Lorion J, Duperron S, Gros O, Cruaud C, Samadi S (2009) Several deepsea mussels and their associated symbionts are able to live both on wood and on whale falls. Proc Biol Sci 276(1654):177-185

Lutz RA, Shank TM, Luther GW, Vetriani C, Tolstoy M, Nuzzio DB, Moore TS, Waldhauser F, Crespo-Medina M, Chatziefthimiou AD, Annis ER, Reed AJ (2008) Interrelationships between vent fluid chemistry, temperature, seismic activity, and biological community structure at a mussel-dominated, deep-sea hydrothermal vent along the East Pacific Rise. J Shellfish Res 27:177-190

Marcus J, Tunnicliffe V, Butterfield D (2009) Post-eruption succession of macrofaunal communities at diffuse flow hydrothermal vents on Axial Volcano, Juan de Fuca Ridge, Northeast Pacific. Deep Sea Res Part II 56:1586-1598

Matabos M, Cuvelier D, Brouard J, Shilito B, Ravaux J, Zbinden M, Barthélémy D, Sarradin PM, Sarrazin J. Behavioural study of two hydrothermal crustacean decapods: Mirocaris fortunata and Segonzacia mesatlantica, from the Lucky Strike vent field (Mid Atlantic Ridge). Deep Sea Res Part II In press

McArdle BH, Anderson MJ (2001) Fitting multivariate models to community data: a comment on distance-based redundancy analysis. Ecology 82:290-297

Mullineaux LS, Peterson CH, Micheli F, Mills SW (2003) Successional mechanism varies along a gradient in hydrothermal fluid flux at deep-sea vents. Ecol Monogr 73:523-542

Murton BJ, Klinkhammer G, Becker K, Briais A, Edge D, Hayward N, Millard N, Mitchell I, Rouse I, Rudnick M, Sayanagi K, Sloan H, Parson L (1994) Direct evidence for the distribution and occurrence of hydrothermal activity between $27^{\circ}-30^{\circ} \mathrm{N}$ on the Mid-Atlantic Ridge. Earth Planet Sci Lett 125:119-128

Muthumbi AW, Vanreusel A, Duineveld G, Soetaert K, Vincx M (2004) Nematode community structure along the continental slope off the Kenyan Coast, Western Indian Ocean. Int Rev Hydrobiol 89:188-205
Ondréas H, Cannat M, Fouquet Y, Normand A, Sarradin PM, Sarrazin J (2009) Recent volcanic events and the distribution of hydrothermal venting at the Lucky Strike hydrothermal field, Mid-Atlantic Ridge. Geochem Geophys Geosyst 10(2):1-18

Platt HM, Warwick RM (1983) A synopsis of the freeliving marine nematodes. Part I: British Enoplids. Cambridge University Press, Cambridge

Platt HM, Warwick RM (1988) A synopsis of the freeliving marine nematodes. Part II: British Chromadorids. Cambridge University Press, Cambridge

Sarradin PM, Caprais JC, Riso R, Kerouel R, Aminot A (1999) Chemical environment of the hydrothermal mussel communities in the Lucky Strike and Menez Gwen vent fields, Mid Atlantic Ridge. Cah Biol Mar 40(1):93-104

Sarradin PM, Waeles M, Bernagout S, Le Gall C, Sarrazin J, Riso R (2009) Speciation of dissolved copper within an active hydrothermal edifice on the Lucky Strike vent field (MAR, $37^{\circ} \mathrm{N}$ ). Sci Total Environ 407:869-878

Sarrazin J, Cuvelier D, Peton L, Legendre P, Sarradin PM (2014) Highresolution dynamics of a deep-sea Hydrothermal mussel assemblage monitored by the EMSO-Açores MoMAR observatory. Deep Sea Res Part I 90:62-75

Sarrazin J, Legendre P, De Busserolles F, Fabri MC, Guilini K, Ivanenko VN, Morineaux M, Vanreusel A, Sarradin PM. Biodiversity patterns, environmental drivers and indicator species on a high temperature hydrothermal edifice, Mid-Atlantic Ridge. Deep Sea Res Pt II In press

Schwabe E, Bartsch I, Błażewicz-Paszkowycz M, Brenke N, Chernyshev AV, Elsner NO, Fischer V, Jażdżewska A, Malyutina MA, Miljutin D, Miljutina M, Kamenev GM, Karanovic I, Maiorova A, Würzberg L. Wood associated fauna collected during the KuramBio expedition in the North West Pacific. Deep Sea Res Part II In press

Sen A, Podowski EL, Becker EL, Shearer EA, Gartman A, Yucel M, Hourdez S, Luther GW, Fisher CR (2014) Community succession in hydrothermal vent habitats of the Eastern Lau Spreading Center and Valu Fa Ridge, Tonga. Limnol Oceanogr 59(5):1510-1528

Setoguchi Y, Nomaki H, Kitahashi T, Watanabe H, Inoue K, Ogawa NO, Shimanaga M (2014) Nematode community composition in hydrothermal vent and adjacent non vent fields around Myojin Knoll, a seamount on the Izu-Ogasawara Arc in the western North Pacific Ocean. Mar Biol 161(8):1775-1785

Shank TM, Fornari DJ, Von Damm KL, Lilley MD, Haymon RM, Lutz RA (1998) Temporal and spatial patterns of biological community development at nascent deep-sea hydrothermal vent $\left(9^{\circ} 50^{\prime} \mathrm{N}\right.$, East Pacific Rise). Deep Sea Res Part II 45:465-515

Shirayama Y (1992) Studies of meiofauna collected from th Iheya Ridge during the dive 541 of the SHINKAI 2000. Proceedings JAMSTEC Symposium. Deep Sea Res 39:287-290

Smith CR, Baco AR (2003) Ecology of whale falls at the deep-sea floor. Oceanogr Mar Biol Annu Rev 41:311-354

Thiermann F, Windoffer R, Giere O (1994) Selected meiofauna around shallow water hydrothermal vents off Milos (Greece): ecological and ultrastructural aspects. Vie Milieu 44:215-226

Thiermann F, Akoumianaki I, Hugjes AJ, Giere O (1997) Benthic fauna of a shallow-water gaseohydrothermal vent area in the Aegean Sea (Milos, Greece). Mar Biol 128:149-159

Thiermann F, Vismann B, Giere O (2000) Sulphide tolerance of the marine nematode Oncholaimus campylocercoides a result of internal sulphur formation? Mar Ecol Prog Ser 193:251-259

Tsurumi M, Tunnicliffe V (2001) Characteristics of a hydrothermal vent assemblage on a volcanically active segment of Juan de Fuca Ridge, Northeast Pacific. Can J Fish Aquat Sci 58:530-542

Tsurumi M, de Graaf RC, Tunnicliffe V (2003) Distributional and biological aspects of copepods at hydrothermal vents on the Juan the Fuca Ridge, north-east Pacific Ocean. J Mar Biol Assoc UK 83:469-477

Tunnicliffe V, Embley RW, Holden JF, Butterfield DA, Massoth GJ, Juniper SK (1997) Biological colonization of new hydrothermal 
vents following an eruption on Juan De Fuca Ridge. Deep Sea Res Part II 44:1627-1644

Van Dover CL (2000) The ecology of deep-sea hydrothermal vents. Princeton Univ. Press, Princeton

Van Dover CL, Desbruyeres D, Segonzac M, Comtet T, Saldanha L, Fiala-Medioni A, Langmuir C (1996) Biology of the Lucky Strike hydrothermal field. Deep Sea Res Part I 43:1509-1529

Van Gaever S, Moodley L, de Beer D, Vanreusel A (2006) Meiobenthos at the Arctic Håkon Mosby Mud Volcano, with a parental-caring nematode thriving in sulphide-rich sediments. Mar Ecol Prog Ser 321:143-155

Van Gaever S, Olu K, Derycke S, Vanreusel A (2009) Metazoan meiofaunal communities at cold seeps along the Norwegian margin: Influence of habitat heterogeneity and evidence for connection with shallow-water habitats. Deep Sea Res Part I 56:772-785

Vanreusel A, Van den Bossche I, Thierman F (1997) Free-living marine nematodes from hydrothermal sediments: similarities with communities from diverse reduced habitats. Mar Ecol Prog Ser 157:207-219

Vanreusel A, De Groote A, Gollner S, Bright M (2010) Ecology and biogeography of free-living nematodes associated with chemosynthetic environments in the deep sea: a review. PLoS ONE 5(8):e12449

Warwick RM, Howard HM, Somerfield PJ (1998) A synopsis of the freeliving marine nematodes. Part III: Monhysterids. Field Studies Council, Shrewsbury, 296 p

Wieser W (1953) Die Beziehung zwischen Mundhoehlengestalt, Ernaehrungsweise und Vorkommen bei freilebenden marinen Nematoden. Arkiv Zool 2-4:439-484

Zekely J, Gollner S, Van Dover CL, Govenar B, Le Bris N, Nemeschkal H, Bright M (2006a) Nematode communities associated with tubeworm and mussel aggregations on the East Pacific Rise. Cah Biol Mar 47:477-482

Zekely J, Sørensen MV, Bright M (2006b) Three new nematode species (Monhysteridae) from deep-sea hydrothermal vents. Meiofauna Mar $15: 25-42$

Zekely J, Van Dover CL, Nemeschkal HL, Bright M (2006c) Hydrothermal vent meiobenthos associated with mytilid mussel aggregations from the mid-Atlantic Ridge and the East Pacific Rise. Deep Sea Res Part I 53:1363-1378

Zeppilli D, Sarrazin J, Leduc D, Martinez Arbizu P, Fontaneto D, Fontanier C, Gooday AJ, Møbjerg Kristensen R, Ivanenko VN, Sørensen MV, Vanreusel A, Thébault J, Mea M, Neves RC, Allio $\mathrm{N}$, Andro T, Arvigo A, Autret M, Bourdonnay L, Castrec J, Claireaux M, Coquillé V, Danielo M, De Wever L, Rachel D, Foulon V, Fumeron R, Hermabessiere L, Hulot V, James T, Langonne-Augen R, Le Bot T, Long M, Mahabror D, Marchant J, Morel Q, Pantalos M, Pouplard E, Raimondeau L, Rio-Cabello A, Seite S, Toomey L, Traisnel G, Urvoy K, Van Der Stegen T, Weyand $M$, Fernandes D. Potential effects of climate change and other anthropogenic threats: is the meiofaunal compartment the best indicator of change for marine benthic communities? Submitted to this Special Issue

Zeppilli D, Danovaro R (2009) Meiofaunal diversity and assemblage structure in a shallow-water hydrothermal vent in the Pacific Ocean. Aquat Biol 5:75-84

Zeppilli D, Bongiorni L, Cattaneo A, Danovaro R, Santos RS (2013) Meiofauna assemblages of the Condor Seamount (North-East Atlantic Ocean) and adjacent deep-sea sediments. Deep Sea Res Part II 98:87-100. doi:10.1016/j.dsr2.2013.08.009 